\title{
RECENZZOVANT? CLLANERS
}

Ing. František Mičánek, plk. Ing. Radek Dubec, Ph.D.

Kariérní ŕád jako podsystém řízení lidských zdrojů v rezortu obrany ČR - formulace problému jeho př́pravy a zavedení

Preparation and Implementation of the Career Order as a Subsystem of Human Resource Management in the Ministry of Defence of the Czech Republic - Problem Formulation Analysis

\begin{abstract}
Abstrakt:
Jedním z cilů projektu rozvoje organizace s názvem „, Trendy výstavby ozbrojených sil České republiky ve vazbě na vývoj bezpečnostního prostředi" je mimo jiné identifikovat směry vývoje v oblasti řzeni kariér a celoživotního vzdělávání v rezortu MO. V článku jsou prezentovány závěry dílči studie, jejímž cílem bylo s použitím manažerských metod provést sběr primárních dat a vytvořit úplnou formulaci problému př́pravy a zavedeni karierniho řádu jako podsystému rízení lidských zdroju v podmínkách rezortu obrany $\breve{C} R$. V prvni části jsou charakterizovány možné metody a nástroje pro formulováni problémů prípravy a zavedení kariérního rádu. Ve druhé části jsou tyto metody prakticky použity a s pomoci výsledků a jejich závěru je pak formulován klíčový problém připravy a zavedeni kariérního řádu. $\mathrm{Na}$ základě identifikovaných nedostatků jsou v závěru článku definována pravidla a doporučeni pro řě̌ení.
\end{abstract}

\section{Abstract:}

One of the objectives of the project for organization development titled "Trends in development the Armed Forces of Czech Republic in relation to the development of the security environment", is to identify trends in career management and life-long education in the MoD. The article presents partial findings of the substudy focused at proper use of management methods to execute primary data collection and to construct complete problem formulation for both preparation and implementation of Career Order as a part of human resources management in the Ministry of Defense. There is summary of methods and tools used for problems formulation in the first part, the second part shows how these methods are applied in practice. Based on results, the conclusion is then formulated depicting the primary problem of preparation and implementation of the career system. 


\section{Klíčová slova:}

Systém řízení lidských zdrojů, trendy výstavby ozbrojených sil, analýza problému, PESTLE analýza, analýza zainteresovaných stran, dimenzionální analýza, Vensim, výzkumné otázky, klíčový problém.

\section{Keywords:}

Human Resource Management, Armed Forces Development Trends, Problem Analysis, PESTLE Analysis, Stakeholder Analysis, Dimensional Analysis, Vensim, Research Questions, Key Problém.

\section{Úvod}

Centrum bezpečnostních a vojenskostrategických studií (dále jen CBVSS) v současné době řeší projekt Univerzity obrany pro rozvoj organizace „TRENDY“ (Trendy výstavby OS ČR ve vazbě na vývoj bezpečnostniho prostředi). Součástí tohoto projektu je dílčí projekt Trendy vývoje v oblasti řizení kariér a celoživotního vzdělávání v rezortu MO, jehož cílem je definovat základní trendy př́pravy personálu v návaznosti na systém řízení kariér s důrazem na kariérové vzdělávání důstojníků a vytvořit tak východiska pro další výzkum, experimentální vývoj a inovace.

Pro dosažení výše uvedeného cíle je však nejprve nutné popsat problematiku řízení kariér jako součásti managementu lidských zdrojů ve státní organizaci s komplexní hierarchickou strukturou a specifickou organizační kulturou (jakou je rezort Ministerstva obrany ČR) a také posoudit, zda, případně do jaké míry jsou splněny nezbytné předpoklady pro úspěšnou implementaci systému řízení kariér v rezortu obrany ČR. Vyjdeme-li z odborné literatury [12] [13] zabývající se problematikou lidských zdrojů a kreativně ji obohatíme nejlepšími zkušenostmi z praxe, můžeme následně definovat jedenáct základních funkcionalit managementu lidských zdrojů. Jde o:

1. Personální plánování - odhady a přepočty potřeby pracovníků v návaznosti na úkoly, které organizace plní.

2. Analýza práce - vymezení pracovních míst a funkcí, zpracování popisů práce, stanovení kvalifikačních předpokladů a požadavků na pracovníky.

3. Získávání a výběr pracovníků - zajištění obsazení volných pracovních míst pracovníky s nejlepšími předpoklady k vykonávání dané práce, zajištění dostatečně široké náborové základny, nastavení pravidel pro objektivní a transparentní výběrová řízení.

4. Rozmístění a kariéra pracovníků - přijímání, zařazování, povyšování, přemist'ování, propouštění atd.

5. Kvalifikační př́íprava a rozvoj pracovníků - zajištění nepřetržitého (celoživotního, kariérového, odborného a jazykového) vzdělávání vzhledem k potřebám ministerstva.

6. Hodnocení pracovníků - periodické či kariérové hodnocení pracovního výkonu pracovníků postavené na principu maximální objektivity a veřejné kontroly. 
7. Motivace a stimulace pracovníků - hmotné a nehmotné pobídky, zabezpečení nejen základních, ale i vyšších sociálních potřeb pracovníků.

8. Odměňování pracovníků - mzda, plat, odměny.

9. Pracovní vztahy - nastavení organizační kultury a klimatu v organizaci, pravidelný monitoring a vyhodnocování důvodů $\mathrm{k}$ nespokojenosti a odchodovosti v organizaci.

10. Pracovní podmínky - pracovní doba, pracovní režim, prostředí, ochrana zdraví při práci.

11. Personální informační systém - zaznamenávání a zpracování údajů o pracovnících, podpora systému řízení kariér.

Vlastní řízení kariér (nebo chcete-li kariérní řád) je soustředěno v bodech 3. až 6 . Další činnosti tvořící systém řízení lidských zdrojů uvedené pod body 1. a 2. vytváří předpoklady nezbytné pro zavedení kariérního řádu, kdežto činnosti pod pořadovým číslem 7.-11. zabezpečují podmínky pro jeho dlouhodobou udržitelnost.

První pokus formulovat kariérní rád rezortu obrany ČR jako samostatný dokument pochází z roku 1995 [14]. Kariérní řád v chápání ministra V. Holáně zde ,,určuje způsob a podmínky povýšení v hodnostech a postupu ve funkcích “. Z hlediska dnešního chápání problematiky řízení lidských zdrojů a jejich kariér se jeví výhodnější hovořit o kariérním řádu jako o ,, souboru legislativních norem, jasně popsaných a veřejně známých pravidel upravujicích průběh služby s cílem zajistit mandatorní pohyb na funkcích (v hodnostech) odpovídajicí požadavkưm na dlouhodobý a udržitelný rozvoj organizace“.

Nastavení, nekonfliktní implementace a dlouhodobá udržitelnost systému řízení lidských zdrojů v podmínkách rezortu obrany ČR jsou podmíněny provedením komplexní (kvantitativní a kvalitativní) analýzy vnitřního a vnějšího prostředí. Z hlediska vnějšího prostředí jde o realistické zvážení dopadů např. demografického vývoje v ČR, vývoje ekonomiky, postoje veřejnosti a politických stran k ozbrojeným silám anebo i stavu národní a mezinárodní legislativy (členství v NATO a EU). U vnitřního prostředí je nezbytné popsat, jaké funkce a činnosti (jak kvalitně, s jakým výsledkem) jsou v rezortu obrany ČR vykonávány v porovnání s teorií personálního managementu a zda může být kariérní řád implementován na současnou organizační strukturu rezortu a počty osob $\mathrm{v}$ hodnostních sborech.

\section{Obecná východiska analytické studie a použité metody}

Dnešní ozbrojené síly ČR jsou relativně technologicky vyspělé a i díky účasti v celé řadě zahraničních operací získaly nemalé bojové zkušenosti. Z hlediska početního stavu a jeho udržitelnosti ale došlo vzhledem k minulosti ke značnému poklesu schopností, naplněnost některých útvarů je v rozmezí 60-80 \% a stále se nedaří zastavit proces vylidňování. Odchodovost byla doposud každoročně vyšší než dosažený rekrutační cíl, atraktivita vojenského povolání zůstává nízká. Reorganizační změny ozbrojených sil v posledních letech byly pouhými pokusy nalézt dočasná východiska z nouzových stavů, které navíc nikdy nebyly dotaženy do konce. [1] Výsledkem je nestabilní a nepředvídatelné prostředí v organizaci, která dlouhodobě ztrácí kvalifikovaný personál, stárne a vylidňuje se. Dnes již platná novela Zákona č. 221/1999 Sb. o vojácích z povolání [2] 
ze dne 9. prosince 2014, společně s prováděcími předpisy by mohla přinést kýženou změnu situace. Úspěšné zavedení této (a jakékoliv jiné) systémové změny ale mimo jiné předpokládá, že jsme schopni identifikovat a následně eliminovat prrípadné těžkosti, které vzniknou při její implementaci.

Pro vymezení problému, jehož některé jevové stránky byly náznakem zmíněny v předcházejícím textu, je nutné primárně identifikovat oblasti (charakteristiky) s významným vlivem na řešenou problematiku a stanovit vhodné analytické nástroje umožňující jejich detailnější popis. K naplnění cíle této analytické studie bylo nezbytné s využitím několika logicky navazujících analytických metod nastavit vhodný systémový přístup k identifikaci klíčových problémů př́pravy a zavedení karierního řádu. Získávání dat vycházelo z použití skupinových technik sběru primárních dat a informací, postupně byly využity metody rozhovorů s hlavními funkcionáři rezortu obrany ČR z let 2012-2015 následované brainstormingem a řízenou diskuzí ve skupině expertů v oblasti personalistiky. Identifikované a vyhodnocené názory a poznatky byly exposteriálně využity pro metody určené k identifikaci problémů. Stručný popis zvolených metod je připojen dále:

PESTL(E) [3] analýza ,,slouži ke strategické analýze faktorů vnějšího prostředí, které by mohly znamenat budoucí príležitosti nebo hrozby pro hodnocenou oblast nebo celou organizaci “ [4]. Metoda byla využita pro identifikaci př́ležitostí a hrozeb vzhledem k systému řízení lidských zdrojů v rezortu obrany. Pro analyzovanou oblast byly vybrány tyto faktory:

- Politické a legislativní - názory na ozbrojené síly a obranyschopnost v programech pol. stran, národní a mezinárodní legislativní rámec.

- Ekonomické - obranný rozpočet, stabilita rozpočtu rezortu obrany, platové podmínky vojáků z povolání.

- Sociální - sociální faktory ovlivňující funkcionality rezortu, důvěryhodnost vojenského povolání, prestiž povolání, demografický vývoj a jeho dopady.

Pro potřeby vnitřní analýzy rezortu obrany se zaměřením na organizační strukturu a počty osob v hodnostních sborech byl zvolen Software Vensim(C. Jde o software určený pro tvorbu modelů s využitím systémové dynamiky, který slouží k převedení statických prríčinných diagramů do podoby dynamických modelů a simulátorů. Kromě jiného lze tento nástroj úspěšně použít pro návrh a posouzení politik, návrh nových reálně použitelných strategií a struktur vedoucích k nápravě problému, posouzení možných nastavení systémů, If-then analýzy [5] a posouzení vzájemných interakcí mezi různými proměnnými systému (protichůdné a navzájem se kompenzující vlivy).

Dimenzionální analýza byla použita v duchu svého účelu jako ,,analýza problému z hlediska několika dimenzí, klíčové aspekty směřjí na podstatu problému a pomáhaji odhalit, za jakých okolností a v jakých dimenzích k problému došlo " [4]. Metoda je založena na pragmatickém a racionálním př́istupu k řešení problému, kdy postupně procházíme předmětovou, prostorovou, časovou, kvantitativní a kvalitativní dimenzi, v nichž se snažíme najít hlavní charakteristiky problému, případné spojitosti či žádané stavy.

Další velmi důležitou charakteristikou pro zavedení nového systému řízení lidských zdrojů je značné množství zúčastněných aktérů, jichž se př́prava a implementace diskutované změny bezprostředně dotýká a na nichž současně závisí úspěch či neúspěch reformy. Pro identifikaci a popis těchto aktérů je nejvhodnější metoda analýzy zainteresovaných stran. Eden a Ackerman [6] definují zainteresovanou stranu z hlediska 
její moci, vlivu a zájmu takto: „Lidé nebo malé skupiny s mocí ovlivnit, vyjednat nebo měnit strategickou budoucnost organizace ". Naproti tomu Freeman [7] volí obecnější př́stup a popisuje zainteresovanou stranu tímto způsobem: ,, ...jakákoli skupina nebo osoba, která je nebo může být ovlivněna naplněním cílů organizace. "Techniky k vytvoření seznamu zainteresovaných stran uvádí např. Brynsson [8].

Proces posouzení zainteresovaných stran obecně probíhá ve třech krocích. Těmi jsou správná a úplná identifikace stran, posouzení jejich vlivu a zájmů a konečně vytvoření vhodné strategie jako klíčové podmínky pro úspěch (jakéhokoli) projektu. Pokud bude nějaká strana opomenuta, lze předpokládat, že bude cíleně pracovat $\mathrm{v}$ náš neprospěch. Bude-li však zahrnuta do našich úvah a vytvoříme pro ni vhodnou strategii, stane se naším aktivním podporovatelem. Úplnou představu o procesu rrízení zainteresovaných stran lze získat z následujícího obrázku č. 1 .

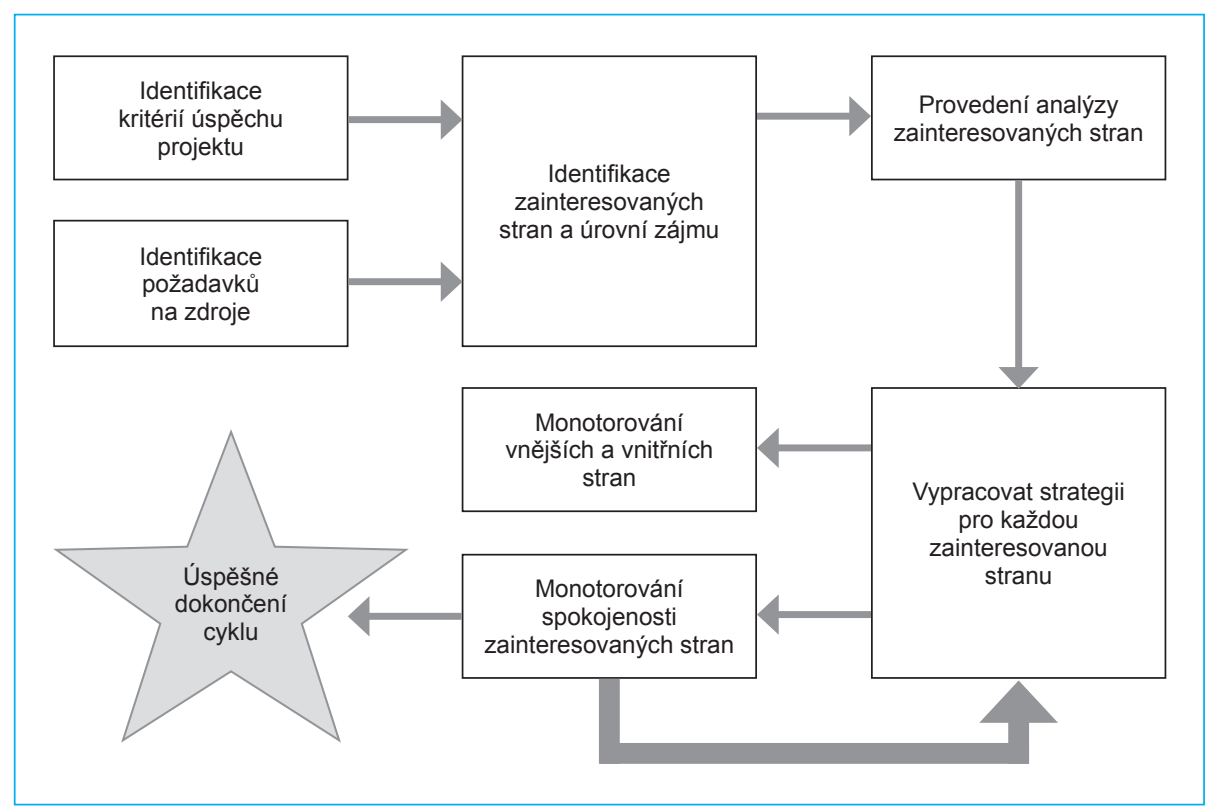

Obrázek č. 1: Proces řízení zainteresovaných stran

Zdroj: [11] 


\section{Výstupy z analýz}

Z důvodu nutnosti dodržení limitovaného rozsahu článku jsou výsledky studie pro publikaci shrnuty do přehledných tabulek a grafů. Charakteristiky vnějš́ího prostředí uvádí tabulka č. 1 .

Tabulka č. 1: Analýza vnějšího prostředí PESTL(E)

\begin{tabular}{|c|c|c|}
\hline & Př́íležitosti & Hrozby \\
\hline $\begin{array}{l}\text { Politicko- } \\
\text {-legislativní } \\
\text { vlivy }\end{array}$ & $\begin{array}{l}\text { Nové dokumenty a legislativa } \\
\text { v jasně dané hierarchii a návaznos- } \\
\text { tech nastaví strategické cíle, prio- } \\
\text { rity a zdroje v dlouhodobém rámci } \\
\text { a budou konsenzuálními doku- } \\
\text { menty vládních i opozičních stran. } \\
\text { Vybalancování úkolů a zdrojů. }\end{array}$ & $\begin{array}{l}\text { Různorodost názorů na obranyschopnost ČR, } \\
\text { velikost a charakter našich OS, rezort obrany } \\
\text { není a nebude kvůli svému charakteru priorit- } \\
\text { ním pro žádnou politickou stranu, chybějící } \\
\text { politická kontinuita a stabilita, nedokončená } \\
\text { a myšlenkově neprovázaná branná legislativa, } \\
\text { absence aktuálních koncepčních a strategických } \\
\text { (dlouhodobých) dokumentů. Nedokončování } \\
\text { transformačních procesů. }\end{array}$ \\
\hline $\begin{array}{l}\text { Ekonomické } \\
\text { faktory }\end{array}$ & $\begin{array}{l}\text { Schválený záměr postupného } \\
\text { nárůstu kapitoly } 307 \text { na } 1,4 \text { \% HDP } \\
\text { v roce } 2020 \text {, možnost přejít na jiný } \\
\text { systém financování obrany umož- } \\
\text { ňující efektivní čerpání finančních } \\
\text { prostředků (např. fondový systém). }\end{array}$ & $\begin{array}{l}\text { Stagnace, př́padně další pokles rozpočtu } \\
\text { na obranu, kontraproduktivní snaha udržet } \\
\text { mandatorní výdaje pod } 50 \% \text {, nevhodně nasta- } \\
\text { vený poměr MV/BV/PF [9], nerovnoměrné } \\
\text { navyšování rozpočtu v letech, neschopnost } \\
\text { realizovat akvizice. }\end{array}$ \\
\hline $\begin{array}{l}\text { Sociální } \\
\text { faktory }\end{array}$ & $\begin{array}{l}\text { Zhoršené bezpečnostní prostředí } \\
\text { má a bude mít za následek ochotu } \\
\text { akceptovat vyšší výdaje na zbro- } \\
\text { jení, tvorba systému hmotných } \\
\text { a nehmotných motivačních pobídek } \\
\text { (platy, zvýhodnění vojáků v záloze } \\
\text { a aktivních záloh ve státní službě } \\
\text { apod.) Změna požadavků na kva- } \\
\text { litu náborováného personálu, zvý- } \\
\text { šení procenta žen a cizích státních } \\
\text { příslušníků v OS. }\end{array}$ & $\begin{array}{l}\text { Sporná podpora veřejnosti, pokračování pro- } \\
\text { cesu odcizení se a uzavření armády jako úzké } \\
\text { profesní skupiny, chybějící edukace mladé } \\
\text { generace v oblasti bezpečnosti, obranyschop- } \\
\text { nosti, hrdosti a tradicím. Negativní demogra- } \\
\text { fický vývoj do roku } 2020 \text {, špatný zdravotní } \\
\text { stav a nízká fyzická kondice mladé generace, } \\
\text { neschopnost vyrovnat úbytky personálů, } \\
\text { neefektivní náborová kampaň, nedostatečný } \\
\text { marketing, neexistující spolupráce s ostatními } \\
\text { rezortu v oblasti práce s personálem. }\end{array}$ \\
\hline
\end{tabular}

\section{Vnitřní prostředí - kvantitativní modelování problému}

Data nezbytná pro kvantitativní modelování v programu Vensim@ ( byla získána od pracovníků Sekce personální MO, Agentury personalistiky AČR a SRPS MO. K modelování byla použita platná organizační struktura, popsaná tabulkami počtů, dále pak skutečné počty příslušníků jednotlivých hodnostních sborů a konečně i tzv. „rozpočtové počty“, udávající, na kolik svých zaměstnanců (vojáků) naplánoval rezort obrany finanční prostředky v části mandatorních výdajů rozpočtu. Byla provedena analýza náboru a odchodovosti za minulých 7 let, zahrnuty věkové hranice pro odchod do starobního důchodu a prvního nástupu na služební místo a následně identifikovány hlavní proměnné, ovlivňující celkové chování systému:

Nábor - mění se v návaznosti na demografický vývoj, konkurenceschopnost rezortu obrany, vývoj veřejného mínění a prováděný marketing;

Počty služebních míst $\mathbf{v}$ hodnostních sborech - odvijí se od požadované velikosti armády dané jejími úkoly, vojensko-politické rozhodnutí;

Doba rozhodná - definovaná zákonem v rozmezí 2-15 let, hlavní parametr pro nastavení kariérního řádu; 
Nastavení průběhu kariéry, optimální doba setrvání v hodnost - rozhodnutí hlavních funkcionářù rezortu (dále HF) o charakteru průběhu kariéry vojáka. Respektuje požadavek na střídání velitelských, štábních a akademických pozic s cílem dosáhnout optimální využití jeho schopností a získání všestranného rozhledu ve prospěch rezortu.

Věková struktura v hodnostech - je závislá na velikosti náboru, nastavení průběhu kariéry a rychlosti rotace na funkčním místě podle vzorce: vyšší nábor = kratší doba rozhodná $=$ rychlejší rotace a postup kariérou = snížení věkového průměru, platí i obráceně;

Využitelnost personálu - nastavení pravidel pro přechod mezi hodnostními sbory a kariérami, uplatnění hlavně u přechodu z poddůstojnického do praporčického sboru;

Finanční zatížení systému, výplata sociálních dávek - každému vojákovi po odsloužení 15 let při odchodu z aktivní služby náleží sociální dávka, určitá část vojáků odejde před dosažením této hranice vzhledem k charakteru vykonávané práce, závisí na velikosti náboru.

Výsledky modelování byly pro větší přehlednost shrnuty do tabulek (viz tabulka č. 2) s doporučením, jak upravit počty funkčních míst $\mathrm{v}$ jednotlivých hodnostech pro nastavení řiditelného systému. Dále byly identifikovány minimální počty náborovaných a propouštěných osob pro různé varianty doby rozhodné pro důstojnický, praporčický i poddůstojnický sbor (setrvání na jednotlivých funkčních místech), př́klad viz obrázek č. 2.

Tabulka č. 2: Návrh úpravy počtů služebních míst v jednotlivých hodnostech

\begin{tabular}{|c|c|c|c|c|c|c|}
\hline Hodnost & $\begin{array}{c}\text { Počty } \\
\text { listopad } \\
2013 \\
\text { GŠ AČR }\end{array}$ & $\begin{array}{c}\text { Počty } \\
\text { leden } 2014 \\
\text { GŠ AČR }\end{array}$ & $\begin{array}{c}\text { Kalkulační } \\
\text { počty } 2014 \\
\text { GŠ AČR }\end{array}$ & 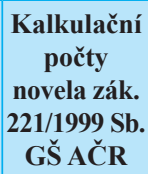 & $\begin{array}{l}\text { Tabulkové } \\
\text { počty zák. } \\
221 / 1999 \\
\text { Sb. } \\
\text { GŠ AČR }\end{array}$ & $\begin{array}{c}\text { Doporučená } \\
\text { změna }\end{array}$ \\
\hline Svobodník & 989 & 713 & 761 & 791 & 1312 & KP 991, ТP 1512 \\
\hline Desátník & 2697 & 2561 & 2743 & 2737 & 4319 & ТP 4119 \\
\hline Četař & 2490 & 2460 & 2575 & 2586 & 3559 & KP 2386 \\
\hline Rotný & 1346 & 1238 & 1284 & 1283 & 1730 & \\
\hline Rotmistr & 2029 & 1913 & 1950 & 1953 & 2329 & KP 2053, ТP 2429 \\
\hline Nadrotmistr & 1614 & 1574 & 1670 & 1677 & 1875 & KP 1577, TP 1775 \\
\hline Praporčík & 1373 & 1367 & 1428 & 1421 & 1519 & \\
\hline Nadpraporčík & 151 & 157 & 167 & 163 & 165 & \\
\hline Štábní praporčík & 3 & 3 & 7 & 7 & 7 & \\
\hline Poručík & 817 & 787 & 724 & 724 & 861 & \\
\hline Nadporučík & 1001 & 964 & 1132 & 1135 & 1286 & \\
\hline Kapitán & 1134 & 1118 & 1240 & 1302 & 1389 & \\
\hline Major & 746 & 726 & 803 & 893 & 913 & \\
\hline Podplukovník & 519 & 512 & 561 & 440 & 449 & \\
\hline Plukovník & 196 & 175 & 206 & 150 & 152 & \\
\hline
\end{tabular}

Zdroj: [10]

Náborové cíle byly následně konstruovány se znalostí dlouhodobé statistiky, že průměrná roční odchodovost vojáků ze zákonných důvodů je 800-1 000 osob, tzv. „odpad““ v průběhu základního výcviku u VeV-VA Vyškov dosahuje cca $25 \%$, obdobně je vysoká i odchodovost studentů UO Brno a konečně na každého znáborovaného zájemce o vstup 


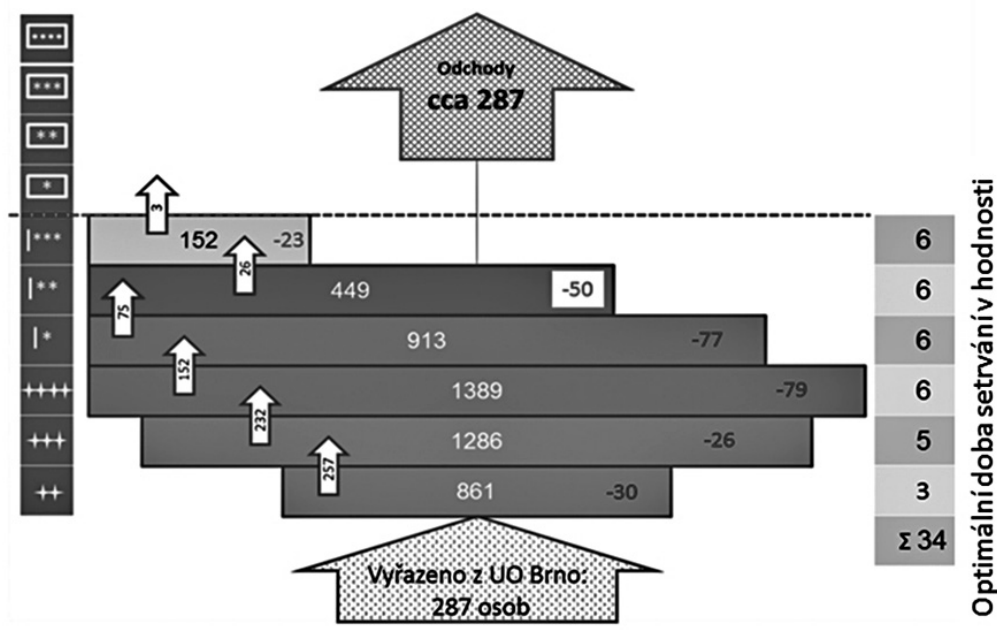

Obrázek č. 2: Model pohybu personálu v kariéře důstojníka, varianta pro TP, novelu 221 a podřízenost NGŠ AČR (viz tabulka výše)

do OS ČR je třeba oslovit cca 15 osob (nevyhovující zdravotní stav a fyzická kondice, zkušenost náborových středisek). Dále uvedená tabulka č. 3 poskytuje srovnání, jak např. rozhodnutí o trvání doby rozhodné (nebo doby setrvání v hodnosti) variantně 6 let / 4 roky změní požadavky na náborové cíle, př́íklad propočítán pro zachování stávajícího stavu - pouze eliminace odchodovosti a stabilizace současných počtů.

Tabulka č. 3: Kalkulace náborových cílů, varianta stabilizace rezortu na stávajících počtech.

\begin{tabular}{|c|c|c|c|c|c|c|c|c|}
\hline \multirow{2}{*}{$\begin{array}{l}\text { Počet } \\
\text { (osob) }\end{array}$} & \multicolumn{2}{|c|}{ Potřeba rezortu } & \multicolumn{2}{|c|}{$\begin{array}{c}\text { Nástup do } \mathrm{ZV} \\
\text { Vyškov }\end{array}$} & \multicolumn{2}{|c|}{ Nástup na UO } & \multicolumn{2}{|c|}{ Nutno oslovit } \\
\hline & 6 let & 4 roky & 6 let & 4 roky & 6 let & 4 roky & 6 let & 4 roky \\
\hline Důstojníci & 287 & 334 & - & - & 360 & 420 & 5400 & 6300 \\
\hline Poddůstojníci & 660 & 960 & 825 & 1200 & - & - & 12370 & 18000 \\
\hline Celkem & & & & & & & 17770 & 24300 \\
\hline
\end{tabular}

Pokud by bylo cílem postupné navyšování počtů rezortu s cílem odstranit nedoplněnost a dosáhnout např. do roku 2020 naplněnost 90-100\% TMP (tzn. potřeba doplnit cca 5000 osob), znamenalo by to každoročně nejen uhradit zákonný odchod cca 1000 osob, ale nadto zařadit do služby dalších 1000 vojáků, celkem tedy 2000 . Pokud uplatníme stejnou logiku jako v tabulce výše, museli bychom každoročně cíleně oslovit cca 37500 mladých lidí pro variantu doby rozhodné 6 let, a dokonce až 47 tis. pro dobu rozhodnou v délce 4 roky.

Zvážíme-li následně, že v letech 2015-2020 bude každoročně k dispozici ne více než 90000 mladých lidí ve věku 20 let, z toho polovina jistě nesplňující předpoklady pro tento typ povolání (vzdělání, fyzická kondice, zdravotní stav, motivace), ze zbytku 45000 pak ještě polovina dívek (žen v ozbrojených silách by mělo být max. do 20 \%), 
dostaneme se k číslu cca 22500 mužů a 5000 žen, celkem 27500 potenciálně vhodných kandidátů. Při porovnání výše uvedených kvalifikovaných odhadů s údaji v tabulce č. 3 to ve výsledku znamená, že do roku 2020 jsme schopni stabilizovat početní stavy rezortu obrany na dnešních skutečných stavech, nikoli však výrazně navyšovat. Nutno podotknout, že o stejnou náborovou základnu samozřejmě soutěží i další zaměstnavatelé, což nebylo v propočtech zohledněno.

Tabulka č. 4: Dimenzionální analýza problému řízení lidských zdrojů v rezortu obrany ČR

\begin{tabular}{|c|c|c|}
\hline Dimenze & Otázka & Zkoumané oblasti - popis problému \\
\hline Předmětová & CO? & $\begin{array}{l}\text { Není zaveden systém do řízení lidských zdrojů, neexistuje strategie } \\
\text { s definovaným cílovým stavem, je prováděno pouze reaktivní personální } \\
\text { řízení, výkonná a evidenční personalistika. Převažuje funkční přístup } \\
\text { k rrízení. Problém se projevuje jako nedostatek kvalifikovaného } \\
\text { a prripraveného personálu. Problém je náročný na rozhodování a dostupné } \\
\text { zdroje, vyžaduje stabilitu prostředí, pochopení jeho komplexnosti ze strany } \\
\text { HF rezortu obrany a jejich jednotný přístup, prripravený a kvalifikovaný } \\
\text { personál na klíčových ř́dících pozicích systému. Dochází k postupnému } \\
\text { vylidňování rezortu, trend se nedaří zastavit a obrátit. Důsledek je velmi } \\
\text { dobře kvantifikovatelný, existuje vysledovatelný dlouhodobý trend, příciny } \\
\text { jsou komplexní, poznané a dobře popsatelné, nikoli však lehce odstranitelné. }\end{array}$ \\
\hline Prostorová & KDE? & $\begin{array}{l}\text { Jde o komplexní problém, působí na něj vnější (PESTLE) vlivy i vnitřní } \\
\text { prostředí (struktura organizace, její firemní kultura a klima, procesy). } \\
\text { Dotýká se nejen ČR, ale i ostatních zemí. Nejde o izolovaný problém, } \\
\text { obecně se s ním potýkají i další organizace, které nejsou atraktivní } \\
\text { z hlediska nabízených pracovních podmínek. }\end{array}$ \\
\hline Časová & KDY? & $\begin{array}{l}\text { Od roku } 1990 \text { se nepodařilo KŘ implementovat. Intenzivně se problém } \\
\text { začíná projevovat s přechodem na profesionální OS v roce } 2004 \text { a dosažení } \\
\text { jejich limitní velikosti potřebné pro plnění úkolů, závazků a ambicí ČR } \\
\text { (2012). Nejedná se o cyklický problém, ale o narušení systému. Za určitých } \\
\text { podmínek je možná náprava a prechod do rovnovážného stavu. Problém } \\
\text { je reálný, nikoliv abstraktní, v př́padě neřešení hrozí fatální neschopností } \\
\text { OS zabezpečit jejich poslání. }\end{array}$ \\
\hline Kvantitativní & KOLIK? & $\begin{array}{l}\text { Problém je multidimenzionální, má několik př́íčin: dlouhodobé } \\
\text { podfinancování rezortu, nezájem veřejnosti, politickou nestabilitu, zaměření } \\
\text { politiků a HF rezortu na krátkodobé cíle, nekoncepční organizační opatření. } \\
\text { Týká se všech profesionálních vojákủ a také všech zaměstnancủ rezortu } \\
\text { obrany spadajících pod Zákon o státní službě, (obecně ale všude, kde } \\
\text { se předpokládá karierní rủst). Je dobře kvantifikovatelný a lze na něj použít } \\
\text { systémovou dynamiku. }\end{array}$ \\
\hline Kvalitativní & $\begin{array}{l}\text { JAK? } \\
\text { PROČ? }\end{array}$ & $\begin{array}{l}\text { Jde o prioritu priorit. Ostatní materiální statky potřebné pro fungování } \\
\text { rezortu obrany jsou lehce pořiditelné, jejich pořízení a uživání je ale } \\
\text { v poměru s lidskými zdroji jen krátkodobé. Jde o filozofický problém } \\
\text { týkající se hlubokých společenských hodnot. Zaměstnanec musí být } \\
\text { motivován, vzděláván, má svoji vúli, hodnoty, mentální modely, představy } \\
\text { a priority, vučč kterým poméřuje svoje okolí. Je nutné komplexní vidění } \\
\text { problematiky vycházející z reálného posouzení stavu a tradic. }\end{array}$ \\
\hline
\end{tabular}




\section{Analýza zainteresovaných stran a jejich postojů}

Nejprve byla formou brainstormingu ve skupině deseti odborníků z oblasti řízení personálu a vzdělávání sestavena množina zainteresovaných stran, následně formou rrízené diskuze posuzovány jejich zájem, vliv, postoje a motivace. Přidělená hodnocení byla následně zprůměrována, postoje byly popsány na základě dosaženého konsenzu. Výsledek uvádí tabulka č. 5, která je dále převedena do matice zainteresovaných stran (obrázek č. 3) popisující vztah zájem/vliv s naznačením strategie prŕstupu k jednotlivým aktérům.

Tabulka č. 5: Analýza zainteresovaných stran

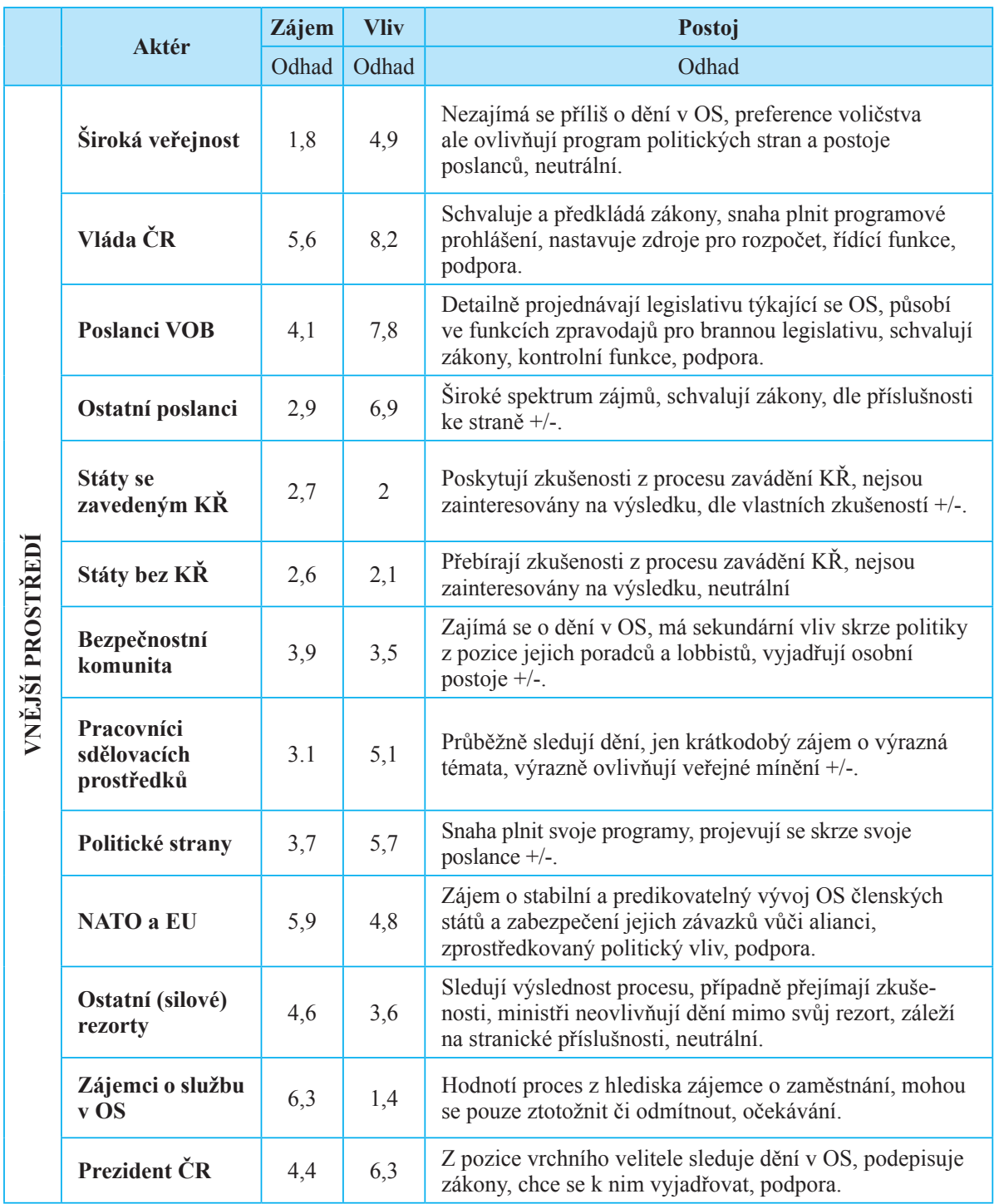


Poračování Tabulkyč. 5

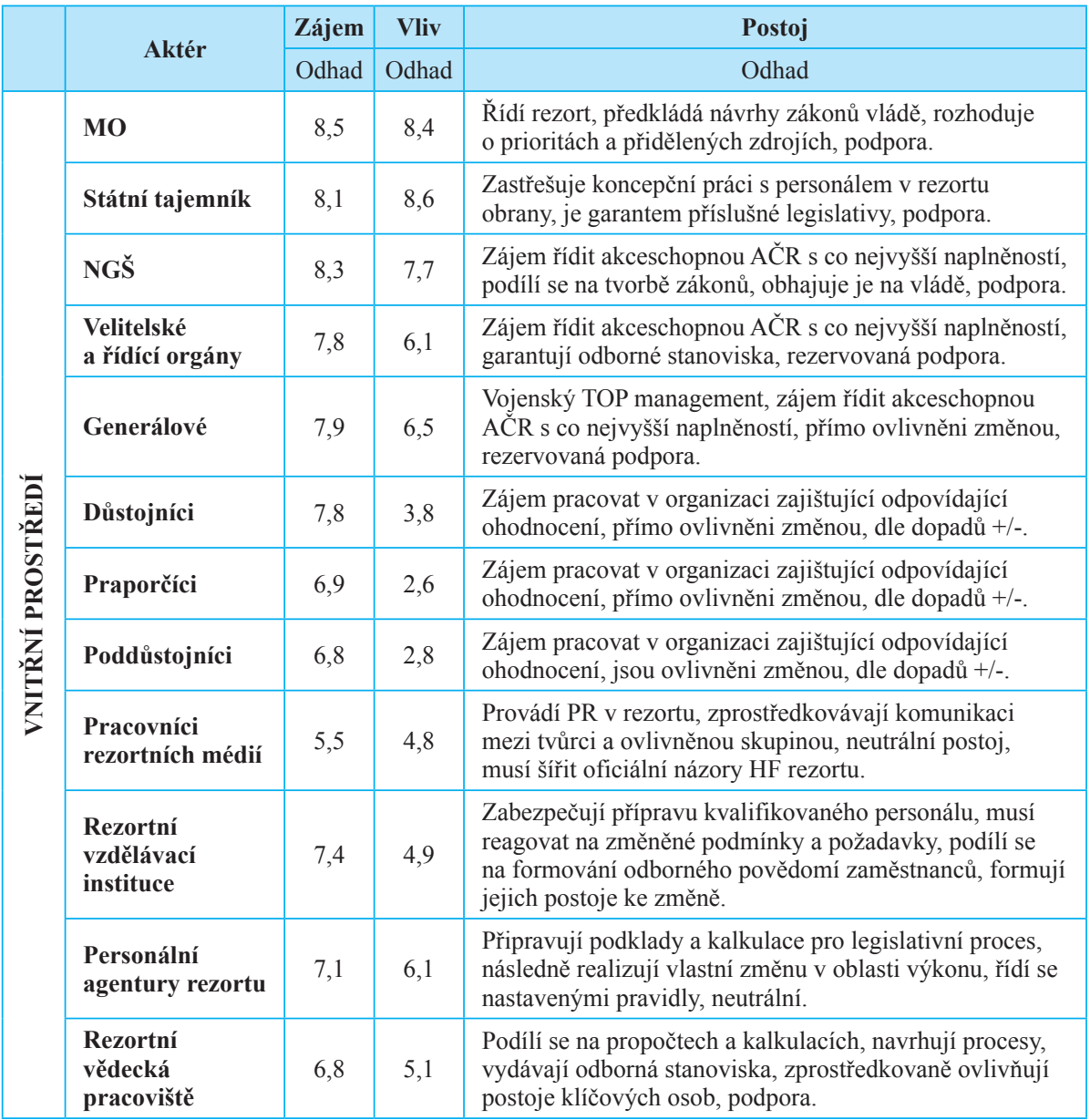

Legenda: Význam (vliv a zájem) zainteresované strany:

0 - nevýznamný předpoklad, vliv a zájem zainteresované strany je zanedbatelný;

9 - významný předpoklad, vliv a zájem zainteresované strany na splnění cíle je podstatný.

Zvláštní pozornost musí být věnována především skupině „Klíčoví hráči“. V jejich př́padě je imperativem nejen perfektní věcná informovanost všech stran této skupiny, ale také dosažení jejich konsenzuálního stanoviska k problematice spojené s včasnými systémovými rozhodnutími, získání povědomí o rizicích a veřejná deklarace ochoty podstoupit je ve prospěch změny. Zainteresovaná strana „Osoby“ naopak musí získat pocit, že změna je v jejich prospěch, že byly maximálně zohledněny jejich potřeby, jejich názory a připomínky jsou reflektovány v rozhodnutích klíčových hráčů. Současně je seznámena s negativními dopady, přičemž se její př́slušníci mohou svobodně rozhodnout o dalším postupu. 

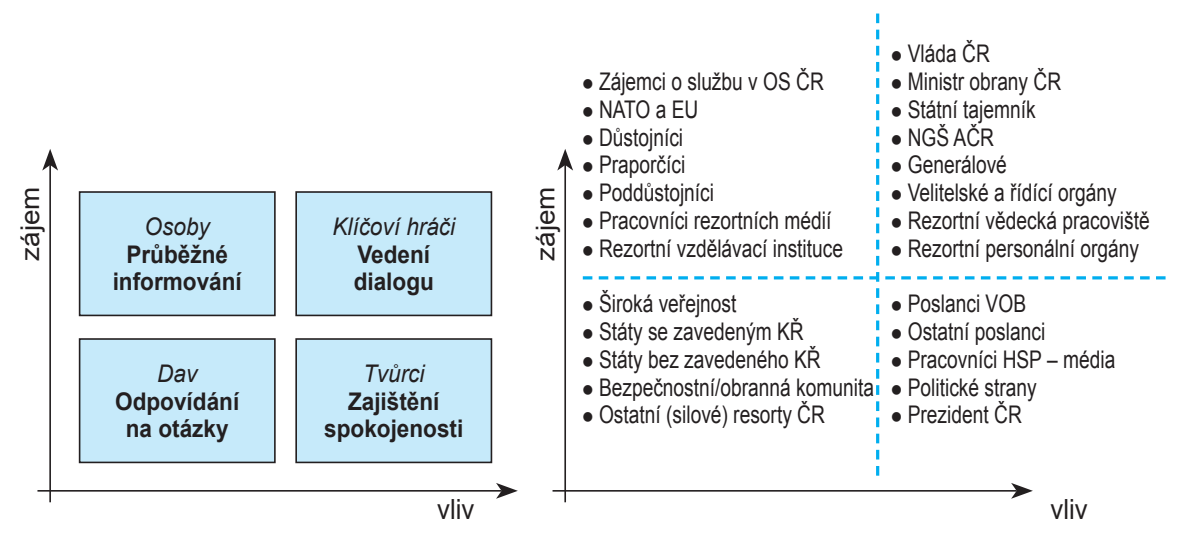

Obrázek č. 3: Matice zainteresovaných stran zájem/vliv

\section{Formulace klíčového problému, závěr}

K vlastní formulaci problému se dostaneme přes syntézu výsledků jednotlivých analýz. Jde o to formulovat sadu negativních výroků popisujících „co je špatně“ a s čím je nezbytné dále pracovat $\mathrm{s}$ cílem popsat problém systému ř́zení lidských zdrojů v rezortu obrany. Výroky jsou formulovány se snahou dosáhnout přibližně stejnou míru obecnosti:

- dlouhodobý nezájem veřejnosti a tím pádem i politických elit, nízká priorita v programech politických stran;

- omezené zdrojové podmínky, jejich nadhodnocená dostupnost a současně nízká efektivita využití;

- chybí skutečný systémový př́istup, převažuje funkční pojetí rízení nad procesním;

- špatně strukturovaný problém, nepochopení jeho rozsahu, hloubky a prríčinných vazeb vychází z nedokonalého popisu systému, absence jasně formulovaných (experimentálně ověřených) pravidel a zásad;

- problém je pouze kvantifikován, není provedena kvalitativní analýza odhalující motivaci dotčených subjektů systému;

- nejednotný náhled a př́istup k problematice u klíčových hráčů, jejich názorová, organizační a personální nestabilita;

- není kalkulováno riziko, neexistují implementační (variantní) strategie „What-If";

- absence komunikačních strategií pro zainteresované strany;

- nedostatek kvalifikovaného a připraveného personálu pro př́pravu a implementaci reformy.

Klíčový problém: „Systém rrizení lidských zdrojů v rezortu obrany není podrobnè popsán jako proces zahrnujicí všechny fáze a funkce managementu lidských zdrojü. Jeho vstupy, výstupy, vazby, aktivity a regulátory (zdroje), stejnějako kličové zainteresované 
strany (osoby) nejsou dostatečně detailně popsány s využitím kvantitativních a kvalitativních analýz. Není zpracována komunikační a implementační strategie s kalkulací rizik, je rozmělněna odpovédnost a působnost."

Cílem studie bylo provést vymezení problému přípravy a zavedení karierního řádu jako podsystému řízení lidských zdrojů v rezortu obrany ČR. Při popisu problému byly předloženy závažné důkazy poukazující na fakt, že v rezortu obrany není prozatím přistupováno $\mathrm{k}$ řešení problémů komplexně a systémově v duchu procesního řízení s využitím relativně jednoduchých manažerských/analytických nástrojů. Oprávněně tedy lze předpokládat těžkosti ve fázi přechodu na nový systém řízení lidských zdrojů. Očekávání klíčových zainteresovaných stran jsou nerealistická a při prvních problémech lze anticipovat vznik deziluze, případně snahu o násilnou a nekoncepční změnu nastavených pravidel. Opakovat se tak znovu může situace, jež je nám známá z minulých let pod pojmem nedokončování transformačních změn. Pracovníci odpovědní za přípravu a následnou implementaci nového systému řízení lidských zdrojů nevyužívají dostupné analýzy a doporučení předkládaná experty v potřebném rozsahu, nevycházejí z reálií vnějšího a vnitřního prostředí rámujícího připravovanou změnu a zaměřují se jen na dosažení dílčích, krátkodobých cílů. Není prováděno průběžné kvalitativní sociologické šetření, které by zkoumalo např. důvody odchodovosti a popsalo postoje a reakce u hlavních zainteresovaných stran, které lze očekávat v souvislosti s připravovanou změnou ř́zení karier.

Hlavní př́ičiny autoři studie vidí v tom, že zásadní reformy nejsou připravovány a široce diskutovány v projektových týmech odborníků zastupujících všechny dotčené strany s dostatečným časovým předstihem, ale pouze jednotlivci a na „poslední chvíli““. Chybí také průběžné (povinné) vzdělávaní personálu v oblasti managementu a strategického ř́zení změny obecně - to se v současnosti dostává pouze vojákům z povolání v běžících karierových kurzech u CBVSS UO Brno, u civilní části MO nic takového zavedeno není. Tím logicky vzniká diskontinuita a vzrůstá riziko neporozumění. Dochází k nadhodnocování zdrojů, efektivita využití těch skutečných je nízká a je podceňován lidský faktor. K tomu, aby bylo dosaženo úspěchu při zavádění kariérního řádu, je nutné na řízení lidských zdrojů nahlížet jako na proces, kdy řídící pracovníci musí vyžadovat a respektovat odborná stanoviska, vrátit se k týmové práci v (efektivních) projektových týmech s jasným delegováním odpovědnosti a popisem cílů metodou SMART, umožňující jejich vyhodnocení a měření.

\section{Poznámky k textu a použitá literatura:}

[1] MIČANEK, F. A kol., Zpráva o stavu zabezpečení obrany ČR v roce 2014 - mýty a realita, Vojenské rozhledy, 2014, roč. 23 (55), č. 2, ISSN 2336-2995 [on-line]; Dostupné z http://www.vojenskerozhledy.cz/ aktuality/2-uncategorised/66-zprava-o-stavu-zabezpeceni-obrany-cr-v-roce-2014-myty-a-realita

[2] ODok. Veřejná Knihovna připravované legislativy. Návrh zákona, kterým se mění zákon č. 221/1999 Sb., o vojácích z povolání, ve znění pozdějších předpisů, a další související zákony. [on-line], [cit. 2014-06-11]. Dostupné z: https://apps.odok.cz/kpldetail?pid=KORN9C2K7NUD

[3] Ekologické a technologické faktory nebyly do analýzy zařazeny.

[4] GRASSEOVÁ, M. (ed.) Efektivní rozhodování: Analyzování, rozhodování, implementace a hodnocení. 1. vydání. Brno: Edika, 2013. 392 s. ISBN 978-80-266-0179-1. 
[5] Kontingenční nebo také simulační analýza, která využívá různé kvalitativní předpoklady spojené se vznikem problému nebo události. Vhodná pro tvorbu scénářů, kde se snažíme najít co možná nejoptimálnější řešení dané situace.

[6] EDEN, C. and ACKERMANN, F. (1998) Making Strategy: The Journey of Strategic Management, p117, London: Sage Publications.

[7] FREEMAN, R. E. (1984) Strategic Management: A Stakeholder Approach, p46, Boston, MA: Pitman.

[8] BRYSON, J. (2004) What to do when stakeholders matter. Public Management Review, 6 (1), p. 21-23. Avaiable at: http://cep.lse.ac.uk/seminarpapers/10-02-03-BRY.pdf

[9] Mandatorní výdaje, Běžné výdaje a Programové financování

[10] KOLKUS. J., MIČÁNEK, F., Modelování personálu, infobriefing NGS AČR dne 13. 11. 2013

[11] GRASSEOVÁ, M a kolektiv. Procesní řízení ve veřejném i soukromém sektoru. [Monografie]. Brno: Computer Press, 2008, 266 s. ISBN 978-80-251-1987-7.

[12] ARMSTRONG, M. Personální management. Praha: Grada Publishing, 1999. ISBN 80-7169-614-5.

[13] JEDINÁK, P. MLÁDKOVÁ, L. Management. Plzeň: Aleš Čeněk, 2009. 273 s. ISBN 978-80-7380-230-1.

[14] Soubor zásad karierního ř́du vojenského profesionála AČR. Model cílového stavu. Praha: MO ČR, $1995,13 \mathrm{~s}$.

Základem každé armády je voják - motivovaný a vycvičený profesionál. Jeho př́iprava a péče o něj, to je má první priorita. Musíme zvýšit nábor, posílit novými vojáky nedoplněné útvary, které plní rozhodující úkoly. Není tajemstvím, že nám chybí 5000 vojáků a potýkáme se i s nenaplněností Aktivní zálohy. Rekrutace nových vojáků, systém jejich kariérového růstu, odborná příprava a schopnost nasazení jsou klíčovými faktory pro rozvoj schopností Armády ČR. V letošním roce se nám po dlouhých letech podaří přijmout více vojáků do armády, než z ní odejde. Roste také zájem občanů o Aktivní zálohu. Aktivní záloha se musí stát naprosto plnohodnotnou součástí našich ozbrojených sil. Musíme všichni vynaložit maximální úsilí k její plnohodnotné integraci do útvarů a zařízení. První kroky již podnikáme a zcela přelomový bude soustředěný výcvik pěších rot Krajských vojenských velitelství na počátku příštího roku. Př́šśí rok bude také rokem, kdy jsem rozhodl, že poprvé od roku 1989 prověŕm procesy a postupy pro zabezpečení mobilizační pohotovosti Armády ČR včetně povolání vojáků v Aktivní záloze na vojenské cvičení.

$\mathrm{V}$ polovině letošního roku vstoupila $\mathrm{v}$ platnost komplexní novelizace zákona č. 221/1999 Sb., o vojácích z povolání. Naším společným úkolem je provést v příštím roce celkové vyhodnocení všech jejích dopadů v reálném životě jednotek.

Z projevu náčelnika Generálního štábu $A \check{C} R$ na velitelském shromážděnív Praze, dne 24. 11. 2015

Převzato z http://www.acr.army.cz/ 